\title{
Public Participation Model for Public Information Disclosure
}

\author{
DADI AHMADI \\ ATIE RACHMIATIE \\ Universitas Islam Bandung, Indonesia \\ NURSYAWAL \\ Sekolah Tinggi Ilmu Komunikasi Bandung, Indonesia
}

\begin{abstract}
Democratic governance is characterized by participation or community involvement in decisionmaking and implementation of public policy. Relating to community participation, the Indonesian government has a policy for citizens to access information they required. As the effect of this policy, Indonesia has made efforts to implement the disclosure of information in accordance with the freedom of information act. This article aims to build model of public participation from the community to control the region government with case "Wakca Balaka Advocacy Forum" and "Kelompok Informasi Masyarakat (KIM)" in the context of public disclosure. The method used was case study and the data were collected through interviews and discussion forum with Wakca Balaka and observation on KIM activities in Bandung, Indonesia. The results of the research showed that Wakca Balaka Advocacy Forum is a bottom up public participation model, due to its own initiative to oversee various local government policies in its implementation. In addition, "KIM" is a "pseudo" public top down participation model, because it is formed and initiated by the government to manage information and empower the community. This makes KIM have a lower critical level in comparison with Wakca balaka in government transparency. For this reason, capacity building for information management officials in the local government and the Information Commission as regulators are needed, and so is building public awareness about the importance of public participation.
\end{abstract}

Keywords: Public participation, public information disclosure, information society group, advocacy forum, governance.

\section{INTRODUCTION}

As stated in the considerations of the Freedom of Information Act (hereafter FOIA), information is an essential need for everyone as well as a part of human rights (Kominfo, 2008). Public disclosure is one of the important characteristics of a democratic country that upholds the sovereignty of the people to realize good governance. Public information is a means to optimizing public oversight of state administration, other public agencies, and everything related to public interest (Mulyana, 2001). A significant implication of the FOIA implementation is public awareness on their rights in governance process and the will to give constructive criticism to the performance of the government, especially in terms of public services. The increase of public knowledge is expected to encourage interest and desire of the community to participate in the governance process in accordance with their respective capacities. On the other hand, the increase of public's ability to criticize the government will enable them to express dissatisfaction when there are problems or imbalances in public service (Tim Open Government Indonesia (OGI), 2012). 
One important factor in the effort to realize Indonesia is included in the ranks of the world's top five, determined by the implementation of good governance. As for running good government, public oversight is required through access to public information disclosure. Clean, effective, democratic and reliable governance can only be realized if the implementation of public information disclosure in the running of the state is running well. In addition, digital transformation is very necessary to improve the performance of government at the central and regional levels. For that reason, the global competitiveness of the Indonesian people can only be achieved if digital transformation goes smoothly, which Indonesia must push smart cities to become smart provinces, to become smart nations (Widiastuti, 2019)

This statement has been stated since December 2014 that, from the Bandung City Government took the initiative to launch a declaration for the implementation of open data Bandung through the Open Data Summit and Challenge (BOSCHA) which is also the implementation of Open Government. Bandung City Government together with Code For Bandung, West Java Incorporated and Bank Indonesia West Java Province collaborate to make Bandung City a pioneer of open data regional government in Indonesia, which aims to foster community participation and innovation in accelerating problem solving in the city of Bandung. This movement has proven to be effective in increasing the performance of the Bandung City Government and increasing the Bandung people's satisfaction index, which in itself has encouraged community participation in various government programs.

One of the implications that is considered very important is the application of the FOI Law is the critical power of the public or the public on the performance of government administration especially public services is increasing and it is estimated that the level of public or public assessment or complaints on the quality of public services is also increasing. Another implication in line with the increasing critical power of the community, is an increase in public knowledge about their rights in public services provided by local governments, so that if one day there is an imbalance or problem in public services, there will be many public complaints relating to the quality of the public service. Increasing public knowledge about the process of governance, is also the implications that will be faced in the application of the FOI Law. This can also increase the interest and desire of the community to participate and participate in the process of governance in accordance with their respective capacities (Subhan, 2016).

Policies on the Mechanism of Community Participation in Government Administration are also needed in order to anticipate the implications of increasing public interest and desire to participate and participate in the process of governance, which substantially regulates the means or media and rules of the game that can facilitate the interests and desires of the community to play a role and participate in the governance process, from participation in development planning and the process of preparing regional development budgets, to monitoring the implementation of development programs and utilizing development budgets.

Central Information Commission announced the ranking of the Public Agency in terms of information disclosure on December, 2018, with the complete results as follows: 


\begin{tabular}{|c|c|c|c|}
\hline Rating & Province & Value & Category \\
\hline 1. & Central Java & 96,95 & Informative \\
\hline 2. & DKI Jakarta & 93,19 & Informative \\
\hline 3. & West Kalimantan & 90,53 & Informative \\
\hline 4. & West Java & 90,32 & Informative \\
\hline 5. & East Java & 51.794 & Moderate Informative \\
\hline 6. & East Kalimantan & 48.380 & Moderate Informative \\
\hline 7. & Banten & 47.769 & Moderate Informative \\
\hline 8. & North Sumatera & 37.223 & Moderate Informative \\
\hline 9. & Papua & 33.518 & Moderate Informative \\
\hline 10. & Bali & 32.270 & Moderate Informative \\
\hline
\end{tabular}

Source: (Komisi Informasi Pusat RI, 2018)

On the other hand, the Forum of West Java Information Openness Advocacy 'Wakca Balaka' assesses that there are still problems in fulfilling the people's right to information from the government in West Java. District / city government and provincial government are still considered closed in fulfilling requests for information from the public regarding the utilization of the Regional Budget (APBD). Even though the disclosure of information from the government can encourage community involvement to participate in various existing programs, the West Java Information Disclosure Advocacy Forum "Wakca Balaka" assesses that the closed attitude of the government will lead to public suspicion of the use of the misused budget. The Information Openness Advocacy Forum in West Java consists of LBH Bandung, INISIATIF Association, WALHI West Java, Budget Discussion Forum (FDA) Kab. Bandung, Kalyana Mandira (KM), Bandung City Education Coalition (KPKB), Family Care Education Association (KerLip), Public Information Development Center (P2iP), Garut Government Watch (GGW), Student and People's Coalition Tasikmalaya (KMRT), Advocacy Institutions Kerakyatan (LAK), AJI (Alliance of Independent Journalists) Bandung, FITRA Sukabumi, Agrarian Reform Consortium (KPA) Jabar.

Besides, according to Regulation of Kementerian Komunikasi dan Informatika RI through Information Society Group / Kelompok Informasi Masyarakat (KIM) or other similar group is a group established by community, from community, and for community to be independently and creatively perform activities which manage information and empowerment to suit the needs (Kominfo, 2010). KIM plays a role in contributing and distributing information to the public as well as the bridge between people and government in the dissemination of information and aspiration. KIM is formed to address and solve common problems through empowerment and access to information (Kominfo, 2017).

Information Society Group (Kelompok Informasi Masyarakat/ KIM) was formed to empower the community by developing the paradigm of communication with the people instead of communication for the people. The provincial government and regency/ municipal develop social communication agencies as partners in the dissemination of information. Dissemination of information is done on a reciprocal basis from the government to the public whether requested or not through mass media and other forms of communication media and/or institutions of public communication. Dissemination of information aimed at educating the nation, empowering and improving the welfare of society, and strengthening the integrity of the state and nation. Dissemination of information directed to creating good governance and encourage public participation in the process of dissemination of information. 
Meanwhile, at the City / District level the results of the ranking of 26 Cities / Regencies in West Java, Bandung ranked 3rd in the index of public information disclosure by referring to the score given by The West Java Regional Commission on aspects of fulfilling periodic information obligations, information at any time that must be provided, information service obligations (Komisi Informasi Daerah Jawa Barat, 2019).

Table 2: Ranking of the Influence of Regency / City Public Information in West Java 2019

\begin{tabular}{llccccccc}
\hline \multirow{2}{*}{ No } & Public Body & Info periodic & $\begin{array}{c}\text { Info } \\
\text { service }\end{array}$ & $\begin{array}{c}\text { Info } \\
\text { official }\end{array}$ & SLIP & $\begin{array}{c}\text { Info } \\
\text { Any ttime }\end{array}$ & $\begin{array}{c}\text { Assist } \\
\text { info }\end{array}$ & $\begin{array}{c}\text { Assesment } \\
\text { Qualification (Rate) }\end{array}$ \\
\cline { 3 - 7 } & $20 \%$ & $12 \%$ & $5 \%$ & $25 \%$ & $30 \%$ & $8 \%$ & $70.45 \%$ \\
\hline 1 & Bekasi city & 64.21 & 88.89 & 93.33 & 80.00 & 76.25 & 20.00 & $67.27 \%$ \\
2 & Bandung Regenc & 74.74 & 68.89 & 100 & 83.75 & 25.00 & 51.25 & $63.95 \%$ \\
3 & Bandung city & 75.79 & 66.67 & 100 & 81.25 & 27.50 & 32.50 & $58.90 \%$ \\
4 & Karawang regnc & 66.32 & 66.67 & 86.67 & 57.50 & 56.25 & 20.00 & $62.92 \%$ \\
5 & Bogor regnc & 62.11 & 86.67 & 100 & 75.00 & 33.75 & 20.00 & $55.11 \%$ \\
6 & Depok city & 68.42 & 88.89 & 63.33 & 65.00 & 25.00 & 20.00 & $51.63 \%$ \\
7 & Subang regency & 48.42 & 82.22 & 66.67 & 55.00 & 37.50 & 20.00 & $50.94 \%$ \\
8 & Garut regency & 35.79 & 77.78 & 73.33 & 61.25 & 37.50 & 20.00 & $49.67 \%$ \\
9 & Kuningan regnc & 50.53 & 40.00 & 100 & 67.50 & 20.00 & 20.00 & $48.52 \%$ \\
10 & Sumedang regnc & 36.84 & 68.89 & 86.67 & 58.75 & 20.00 & 20.00 & \\
\hline
\end{tabular}

Source: (Komisi Informasi Daerah Jawa Barat, 2019)

In terms of ranking, Bandung City is one out of the three best regions in terms of public information, in comparison with that in Bandung Regency and Bekasi City. Even in matters of public information disputes, the City of Bandung, in this case the City Government, is one of the most disputed in KIP of the 132 disputes, the most reported information disputes include financial and budgetary responsibility. If in 2013, Bandung City Government was labeled as the city with the Worst Information Openness System in Indonesia. In 2014 the chart began to rise to rank 17th. Then in 2016, Bandung was surprisingly able to become the 3rd position in the public information disclosure system. The parameters used in measuring aspects of public information disclosure are all of the various qualities exhibited by public bodies, but have not measured public participation as an integral part in the context of public information disclosure.

Therefore, research in terms of this aspect of public participation is important to be carried out in order to obtain information on the context of public information disclosure in a public perspective. For the sake of sharpness of the analysis, the focus of the problem was identified into sub-problems, namely the extent of public information disclosure within the City Government of Bandung and how the model of public participation in particular was carried out by the West Java Information Disclosure Advocacy Forum (Wakca Balaka) and Information Society Group (KIM) with the Bandung City Government. Policies regarding public participation is required with the increase of public interest to take part in the governance process. The substance of this mechanism is to establish rules and provide the means/media to facilitate the community participation, either in development planning and budgeting process or to monitor the implementation of development programs and utilization of the budget. 
The discussion in this study focused on the activities of public participation in the context of information disclosure in Bandung and the role of organizations such as Wakca Balaka and Information Society Groups (hereafter KIM) as a manifestation of public participation in the governance of the city.

\section{LITERATURE REVIEW}

The role of non governmental organizations (NGOs) is very important today in terms of monitoring the performance of the bureaucracy, especially after bureaucratic reform and information disclosure of the Republic. Kinerka bureaucracy supervised in three different contexts, "is controlling the political, administrative controls, and control informally either by outsiders (external) and by actor / Toolkits within the bureaucracy itself (internal). NGOs asorganizations civil society can conduct direct or indirect supervision of bureaucratic institutions" (Setiyono, 2004). In addition, according to Max Weber, bureaucracy must be supported by sources of power, namely confidentiality, information monopoly, technical expertise, and high social status. Critics of bureaucracy say, it is these elements that have given strength to the bureaucracy to control society (Mas'oed, 2003).

Thus, bureaucratic supervision by NGOs is very important in order to reduce the excessive and arrogant nature of bureaucracy. However democracy demands the freedom or openness of public information, so that democratic countries everywhere are equal, namely demanding the participation or active participation of the people in the administration of a state based on equality and independence or freedom. Public disclosure becomes a means for opening up participation and community control over government administration in order to realize good governance (Norsiah, Mohd Sobhi \& Nazialita, 2015).

Experts generally agree that one of the conditions for the realization of democracy is the involvement of the community in public decision making. Lyman Tower Sargent as quoted by $\mathrm{E}$. S. Fatah requires democracy as follows: (1) there is people's involvement in decision making; (2) equality of rights among citizens; (3) there is freedom and independence given or maintained and owned by citizens; (4) an effective representation system; and (5) an electoral system that guarantees respect for the principle of majority rule (Fatah, 1994). The definition of democracy in question generally refers to liberal democracy. However, the liberal democracy model has been corrected by a number of experts, including those carried out by German thinker Jurgen Habermas (Safrudin, 2004).

In Habermas's view, the liberal democratic model relies on representative democracy which is considered inadequate, because with the current of globalization the problem of popular sovereignty presented to the state becomes complex and problematic (Habermas, 2007). This is caused by various forces such as business, both national and international, which reduce the role of the state. In this case, communication becomes important and strategic to reconcile the various roles between the state, the market and the people. Departing from the above conditions, it is offered "deliberative democracy" (deliberative democracy).

In this deliberative democracy model, the intensity of the participation of the people or citizens is increased in the process of forming aspirations and opinions, so that the policies and laws produced by parties to the government are getting closer to the expectations of citizens in general. Intensification of the deliberation process is carried out through public discourse which is a way to realize the concept of democracy itself, namely government by the governed. Thus, "democracy is not merely trapped by electoral 
procedures for electing rulers, but how every public policy always involves the community and community participation is a necessity. In the context of this participation also access to public information is a prerequisite so that the deliberative democratic process gets stronger" (Habermas, 2007). Normally plans may include the analysis of the situation by gathering all the information related to the activity plan (Hidayat, Kuswarno, Zubair, \& Hafiar, 2018)

Therefore, deliberative democracy according to this is in line with the ideals that the government wants to build with the context of public information disclosure, namely that people's sovereignty is in the hands of the people. The people do not lead themselves but continue to control the course of government and participate in the context of various public policies. Deliberative democracy, in fact has long been known in the history of politics in Indonesia with the term "deliberation to reach consensus".

Table 3: Theoretical dimensions of public deliberation

Democratic tendencies Dimensions Undemocratic tendencies

Universal: All individuals affected by Access the issue participate in deliberation

Inclusive: All relevant viewpoints and arguments are equitably expressed Reason-Based: Relies on logic and facts.

Agreement-Oriented: Leads to consensus based on common understandings of the public good and / or acceptance of the legitimacy of whatever disagreement linger.

\section{Strengthens democracy:}

Increases citizens' efficacy, political knowledge, and future participation, and can lead to better, more legitimate policy outcomes

Voice

Elitest: Public deliberation is infrequent and participation in it is selective

Exclusive: Expressed viewpoints and arguments are skewed in favor of entrenched social and economic hierarchies

Type of discourse

Effect on Cohesion

Effect on politics

\section{Emotion and coercion based:}

Unreasoned appeals that are easily manipulated and that disadvantage marginalized groups

Disagreement-oriented: Intensiveies divisions and disagreements or stifles genuine differences.

\section{No or negative effect on democracy : Exerts little impact on citizen knowledge and participation and can strengthen cynicism and disengagement while leading to harmful or short-term policy outcomes.}

Jacobs et al. (2009) explain several theoretical dimensions regarding public deliberation. These dimensions are access, voice, type of discourse, cohesion effects, and political effects on conditions that are classified as democratic or vice versa which are less democratic. It seems that this dimension can be applied as a parameter that will also be used in analyzing public participation, especially in the context of interaction between the West Java Public Information Openness Advocacy Forum and the Regional Government of Bandung Municipality. 
Participation in various public policies can be interpreted as political participation; to this relation, Huntington and Nelson interpreted political participation a civic activity (pivate citizen) which aims to influence decision making by the government (Iza, 2011). Public participation and involvement in the process of public policy making plans, public policy programs, public decision making processes and the reasons for public decision making are one of the characteristics of organizing a democratic state.

In this regard, Bagir Manan said that political freedom is marked by a sense of peace, because everyone feels guaranteed security or safety (Aziz, 2010). In this case, it is also necessary to state the views of Tjandra and W. Riawan Tjandra and Kresno Budi Sudarsono, 2009) which confirms that there are three accesses that need to be provided for the community in the administration of government. First, access to information which includes 2 (two) types, namely passive information access rights and active information rights; Second, access to participation in decision making (public participation in decision making) includes the right of the community to influence decision making, participation in the determination of development policies, plans and programs and participation in the formation of laws and regulations; and third, access to justice (access to justice) by providing a mechanism for the community to enforce environmental law directly (the justice pillar also provides a mechanism for the public to enforce environmental law directly). The nature and role of the openness and transparency (Rachmiatie, 2001).

Habermas states, that the starting point that can be a reference to reorganize the process of involving active community participation is to expand political debate in parliament to civil society (Habermas, 2007). Not only state officials and people's representatives, but also all citizens participate in political discourse to take political decisions together. Through the radicalization of the concept of the classic rule of law the sovereignty of the people shifted from the decision making process in parliament to the process of participation in the public sphere. People's sovereignty is not a frozen substance in the assembly of representatives of the people, but also in various forums of citizens, organizations, non governmental, social movements or in short wherever discourse about the common interests of citizens is carried out. In line with this, Iza (2011) explained that the implementation of the principle of community participation aims to: first, give birth to the principle of carefulness and prudence of public officials in making public policy; and second, bring the consequences of the emergence of a constructive social control and social readiness of the community for any form of impact due to a development activity. A democratic system that involves active participation of the community aims to increase the people's low economic, political and social.

The concept of community participation has different meanings so it needs to be clarified about which processes can be called participation and which are not, so there is a common perspective in assessing a participatory process in the past, present, and future. Furthermore, Ahmad (2017) which refers to Arenstein's opinion, compiles a model that can help to assess the level of participation in a process of forming policies or general regulations. In general there are three degrees of community participation. First, not participatory (non participation); second, apparent (degrees of tokenism); and third, degrees of citizen power. He further said "the basis for determining degrees, not on how far the community has been involved in the process of forming a policy or program carried out by the state but how far the community can determine the final outcome or impact of the policy or program (Martin, Salvosa, Exevea \& Tome, 2018). 
Lowest degree consists of two levels of participation, which are manipulation and therapy. At this level, participation only aims to organize the community and treat wounds arising from the failure of the system and mechanism of government. There is no intention at all to involve the community in developing government activities or programs. The secondary level (pseudo) consists of three levels of participation, namely: notification (informing); consultation; and damping (placation). At this stage there has been an increase in the level of participation, the community can already hear (the level of notice) and be heard (the level of consultation), but this stage does not yet provide a clear guarantee to the public that their votes are taken into account in determining the outcome of a public policy.

While at the damping stage it has indeed allowed the community in general, especially those who are vulnerable to provide more significant input in determining the results of public policy, but the decision-making process is still fully held by the holder of power. The highest degree consists of three levels of participation, the partnership,the delegation of powers, and the top is the control of society. At this stage community participation, including vulnerable ones, is included in the process of determining the process, results and impact of policies. The community can already negotiate with traditional authorities in an equal political position (partnership level). Even further able to direct the policy because the decision-making space has been mastered (the level of power delegation). So that at the final stage community participation has reached its peak, namely when the community is politically and administratively able to control the process, formation, implementation and policy (level of community control).

Regarding the openness, Indonesian government has taken several initiatives to realize a system of open government, namely the establishment of bureaucracy reform, the enactment of Freedom Information Act, and declaration of "Open Government Indonesia" program to encourage transparency and accountability of public bodies and to increase public participation in the development process. In the future, this open government should become a "way of life" in the overall development of governance in Indonesia starting from the center to regions with its focus orientation for the prosperity of the people.

\section{METHODOLOGY}

This study used qualitative method with case study approach, which is a contextual study that puts human beings as an instrument and adapted to the reasonable situation related to data collection (Wahid, 2013). The first thing to note in this methodology is the paradigm of research. Paradigm outline what should be studied, what questions should be asked and what rules must be followed in interpreting the research answers. Qualitative method is qualitative research that has the characteristics as follows: It tends to be unstructured; the concepts used may not gained definition yet nor widely elaborated (it is often use sensitizing concepts, which serves only as an initial and general conceptual overview); formulation of the problem studied may also be discovered only after collecting data in the field: the research instruments are usually unstructured (they are only a general guideline for the depth-interview, which can be developed according to the conditions in which the interviews were conducted) (Hidayat, 2002).

Qualitative research is descriptive, interested in the meaning and understanding through words or images. Qualitative researcher is a fundamental instrument for data collection and analysis (Azlina, 2017). Data is approached through human instruments, rather than inventory, a list of questions or machine. The informant in this research are, the leader of Information and Documentation Information Management (PPID) of Bandung city, 
the leader of Wakca Balaka and 3 person of the leader Information Society Goup (KIM). Researchers physically make contact with people, their background, location or institution to observe or record the behavior in natural setting. Qualitative research is also inductive in which researchers build abstractions, concepts, hypotheses and theories.

\section{RESULTS AND DISCUSSION}

Government of Bandung along with Code For Bandung, West Java Incorporated and Bank of Indonesia West Java Province collaborated to make Bandung as a pioneer of municipal with open data in Indonesia. The goal is to nurture community participation and innovation in accelerating the settlement of the problem in the city, as well as to initiate steps towards open government which is transparent, accountable, and innovative.

Bandung Summit And Open Data Challenge is one of the first steps toward an open data movement within the government, having previously launched a data portal Indonesia (data.go.id) in September 2014, and in December 2014 the Bandung government took the initiative to declare the implementation of open data. The initiative also aims to anticipate the upcoming event of Open Data Day (http://opendataday.org/) which bring together citizens in cities around the world to build applications, open the data, create visualizations and publish analyzes using open public data to support and encourage the adoption of open data policies by local governments, regional and national levels in the world.

\section{WAKCA BALAKA AND IMPLEMENTATION OF PUBLIC PARTICIPATION}

West Java (Jabar) province was selected as the best public institution in the public disclosure (or KIP) in Indonesia in 2012. West Java was also considered successful in implementing Article 9 of the Freedom of Information Act No. 14 of 2008 which describes the information that must be provided and published periodically. The award is given as a part of Right To Know Day International event series in 2012 (Kominfo, 2008).

Responding to the award, "Wakca Balaka" West Java Advocacy Forum of Information Disclosure assessed that there are problems exist in the fulfillment of the public's right to information from governments in West Java. The municipal and provincial governments were considered operated in secrecy upon information request from the public regarding the utilization of municipal budget (APBD), whereas the disclosure of information from the government could encourage the involvement of the community to participate in various programs existed. Wakca Balaka convinced that the government's stance of secrecy will raise suspicion over the potential misuse of public funds.

This is related to many cases upon information request to a public body experienced by Wakca Balaka in West Java. Dadan of the West Java Advocacy Forum of Information Disclosure considers there are gaps between the facts in the field with new appreciation for the accomplishments Jabar received in information disclosure. "We do not agree with the award. It's a mistake, it is not true that Jabar transparent in public information," said Dadan firmly.

Wakca Balaka is an advocacy forum of information disclosure consists of a set of civil society groups in West Java which dedicate to realize their constitutional rights as citizens to access the information in public affairs. Wakca Balaka is composed of Legal Aid Institution (LBH) Bandung, Society of INISIATIF (INITIATIVES), Indonesian Forum for The Environment (WALHI) Jabar, Budget Forum Discussion (FDA) of Bandung regency, Kalya Mandira (KM), Society for Family Care for Education (KerLip), Center for Development of Public Information 
(P2iP), Garut Government Watch (GGW ), Coalition of Students and People of Tasikmalaya (KMRT), Institution for People Advocacy (LAK), Alliance of Independence Journalists (AJI) Bandung, FITRA (Indonesian Forum for Transparency) of Sukabumi, and the Agrarian Reform Consortium (KPA) Jabar, AGGRARIS - Jabar, P3ML (Center for the Study and Development of Local Communities) - Sumedang T.

The name of "Wakca Balaka" derives from the Sundanese language means reveal all things openly without hiding and accordingly represents the purpose of this forum to get information in a transparent and proportionate share from the government or other public bodies. Wakca Balaka most widely filed disputes against government/authorities regarding the issue of public information request with the number and reasons of disputes is 101 cases in 2017, 176 cases in 2018. The reason of dispute is, not fulfilled 19\%, note appropriate $14 \%$, excluded $1 \%$ and $66 \%$ not responded.

\section{WAKCA BALAKA AND GOVERNMENT OF BANDUNG CITY}

Wakca Balaka has once been a companion and advocator for Bandung Education Coalition (KPKB) during a public dispute against Bandung City Education Department (Diknas Bandung) which ended in lawsuit cancellation by Bandung Administrative Court. Reflecting on the case, the fundamental issue of public participation in Bandung is the durability of the applicants to go through all the procedures without being easily distracted by the response of the public body. The public is generally unaware of their rights and do not know the relevance and competence of public institutions in serving the information requested by the public. Many public bodies are still operate in the culture of "secrecy" in fulfilling requests for information or services from the public.

Cancellation also occured in three cases of public information requests in Bandung Administrative Court filed by the Information Commission of West Java Province. Three cases related to educational issues involving the mayor of Bandung and Bandung Department of Education with residents represented by educational organizations. Three decisions of KIP Jabar which cancelled by Bandung Administrative Court were a request for information on Budget Implementation Document of Bandung Department of Education, public information request for copy of the plan and realization of new classrooms construction and learning resource center, and an request for list of new students' names of junior high school (SMP), senior high school (SMA), and vocational high school (SMK) in Bandung. All the lawsuits was cancelled after the long procedures and the impasse in mediation conducted by the Information Commission of West Java province and they forced to take the case to the Administrative Court.

Coordinator of Wakca Balaka Forum, Arip Yogiawan, said the cancellation of the Information Commission decisions based on the reason of legal standing (Decree No 53/G/2012/ PTUN-BDG) on applicant of information and legal defect. "We see there has been a mismatch between openness in Public Information Act and the decisions issued by administrative court," said Arip in Bandung. Wakca Balaka looked at three decisions of administrative court as the evidence that public still have difficulties in accessing their right to obtain information. Here is the path taken by Wakca Balaka in requesting information to Bandung Department of Education and ended up in disputes: 


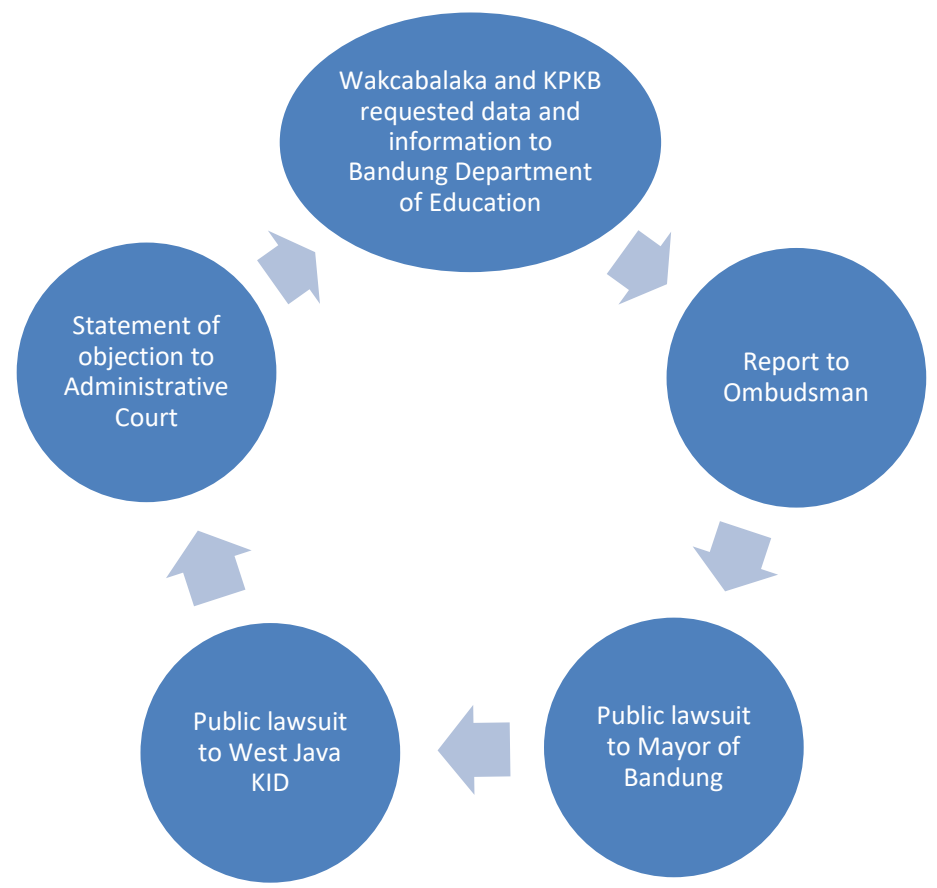

Figure 1: The path of information requests made by Wakca Balaka which ended-up in disputes

Wakca Balaka assumed that the decision of the Administrative Court Judges were denying the philosophy of Freedom of Information Act which only requires Indonesian citizens or Indonesian legal entities authorized as applicant of information. The judges were considered failed to understand the Freedom of Information Act which should emphasize more on the view that access to public information is a basic right of every citizen as well as an instrument for achieving good governance. As it is stated in the law, the right to access public information is a human right which does not have to be limited by legal interest. Public information should be accessible by anyone, ie, by all Indonesian citizens.

Wakca Balaka also assumed the Administrative Court decisions which cancelled West Java Information Commission's decisions due to procedural reasons indicate that West Java KIP is not ready to manage disputes on information. The commissioner of West Java KIP were judged to be unprofessional in their duties because they did not present when KIP Jabar were litigants in Bandung Administrative Court. KIP failed in documenting the local inspection process, did not submit the necessary evidence in the trial, and did not include a statement in the decision of the commissioner which announced that the hearing open to the public. The lawsuit of public information request was canceled by the Administrative Court of Bandung with a variety of reasons after taken almost one year long of negotiation process.

The incident above showed that the implementation of public disclosure is still colored by many problems. Although it guaranteed by the law, it turns out in reality that the public is still experiencing difficulties in accessing public information from public bodies. This problem can lead to another difficulties for people to participate in monitoring the performance of government and impede the implementation of a government which are transparent, accountable, and participatory.

Public disclosure and bureaucratic reform should be consistent, mutually supportive and reinforcing. Disclosure of public information will not be realized if the government bureaucracy does not reform and change the paradigm of governance organization. 
Information which previously closed and inaccessible to the public must be completely open. According to records, in 2012 and 2013 the city of Bandung is still experiencing difficulties in implementing KIP, both from the public bodies and public in general. Reflecting on the case of KPKB accompanied by Wakcabalaka, it can be concluded that until 2013 bureaucracy in Bandung still implement the culture of secrecy.

\section{THE ACTIVITIES OF INFORMATION SOCIETY GROUPS (KIM) BANDUNG}

In addition to PPID web as a medium to answer public's desire in fulfilling information, the government of Bandung is also forming society group that can be used to interact within the community, to express ideas and projects, as well as to connect information and participation between government and society, namely the Information Society Group (hereafter KIM).

KIM Bandung was formed in 2006 based on Secretary of Bandung Circular letter No. 87/SE.006 Diskominfo (Department of Communication and Information Technology) on forming a Society of Information Group (KIM). Until now, Bandung has formed 110 KIM with approvals decision from Lurah (head of the village). KIM guidance is done gradually under the coordination of Bandung Department of Communication and information, particularly under the Unit of Information and Data Processing on Information Dissemination, through socialization and improving the quality of human resources.

Most of the existing KIM has been actively carrying out various activities that support the advancement and welfare of the community. Some of those are KIM Sukabungah by performing activities of information technology development, improving public health, and others; KIM Cibangkong with information technology activities and the development of urban vegetable plants; KIM Babakan Surabaya by applying information technology through radio and social media community to empower the role of the public to actively participate in various development activities.

Information society groups in Bandung stand in line with the development of science and technology which influence the attitude and behavior of the people to get quick service in all aspects of life, including in communication and information. All this time, information is largely dominated by the middle class to upper class and the lower group often overlooked in this information needs due to socio-economic conditions which make them unable to reach it. The lack of information received by the last group encourages the formation of information society as a solution to bridge the gap.

Society in the era of open data, open government and public disclosure are placed as a partner for the government. Pattern of relationship between government and society is built collaboratively with public involvement. Community or the public at the same time participate in the development process of each area. The public has the right to supervise, provide feedback and criticism, advocate for their interests, and actively involved in creating accountable and transparent government through participation.

Freedom of information and public disclosure which are applied appropriately in the knowledgeable community will ensure the accountability of government performance, encourage transparency, and increase public participation in the governance process of central and local levels.

The openness of public information and bureaucratic reform are in line and go hand in hand to support and strengthen each other. However, public information disclosure will not be realized if the government bureaucracy does not reform and change its organizational governance paradigm. Now there are needs for the public to get that once 
completely closed information and access to data as widely as possible. The city of Bandung in 2012 to 2013 still faced various obstacles from both the public institution itself and the public sphere. Based on the case of PKPB accompanied by Wakcabalaka, until 2013 in Bandung there was still a culture of secrecy among the bureaucracy.

However, after the leadership of Mayor Ridwan Kamil, many breakthroughs have been made since 2014 related to government efforts to reform the bureaucracy and public information disclosure. The open data movement as one of the top priorities in improving public services is certainly expected to advance information disclosure in public bodies.

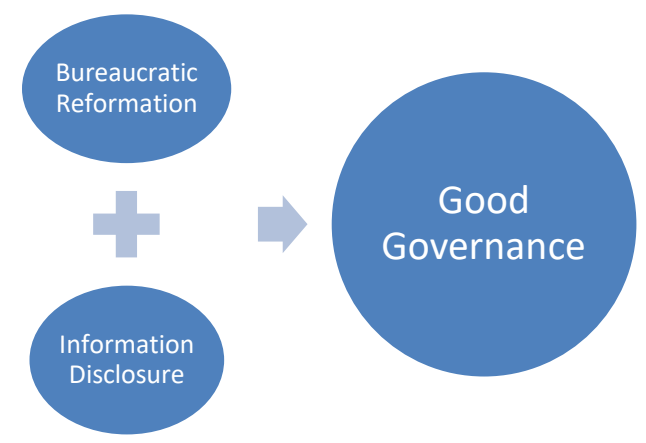

Figure 2: Model Bureaucratic Reformation and Information Disclosure

This model explains that public information disclosure and bureaucratic reform are compatible and mutually supportive, both of which go hand in hand with each other. However, public information disclosure will not be realized if the government bureaucracy does not reform and change its organizational governance paradigm. Of course, which was completely closed and without access to data that is allowed to the public, now there is a need for information demands to be opened to the widest possible public. However, after the leadership of Ridwan Kamil Bandung City Leader, many breakthroughs have been made since 2014, in relation to government efforts to reform bureaucracy and public information disclosure, the open data movement is also a top priority in improving services to the public.

Open data are ultimately expected to be able to build transparency and accountability of government and private public bodies, encourage public participation and improve the quality of public services and save efforts and budgets because all data is available and can be easily accessed both by public policy makers and by the public alone. So that in the end the development process is also carried out by involving the public in the context of its participation, both directly and indirectly. Creighton (2005) sees democracy without community participation as something artificial. What is new is that public participation in the agency's decision making is increasingly considered standard practice. Many recent political theorists argue that it is a defining characteristic of modern democracy. As two British theorists recently put it, "Democracy without citizen deliberation and participation is ultimately an empty and meaningless concept" (Creighton, 2005). So that openness becomes a catalyst for the overall bureaucratic reform process. Open Government encourages progress in coordination and decision making, bureaucratic service performance, public participation and a sense of shared ownership, as well as ensuring the accountability of public bodies and preventing corruption. Open Government, an idea whose meaning is currently being constructed, offers a provocative set of ideas for reconstructing government in ways that could increase and improve the abilities of 
democratic societies to deal effectively, sustainably, and equitably with its issues. In other words, open government, if implemented thoughtfully, could improve our democracy and our civic intelligence while keeping the costs to acceptable and appropriate levels (Schuler, 2010).

With the open government supported by an adequate database, it makes it easy for the bureaucracy to carry out its bureaucratic performance. If all this time decision making has been done internally by public institutions, then with bureaucratic reform and public information disclosure, citizens can be involved directly or indirectly in the process of making public policies. The mechanism has been regulated in the Act. The construction and dissemination of intellectual discourse and information are increasingly vital for social control, ideological persuasion, and hegemonic legitimation (Wan Norshira, 2019).

If before governance reforms seem to stand alone, and citizens are often used as "objects" in the development process, then in the new paradigm of public information disclosure, through bureaucratic reforms are encouraged so that the public is placed as a "subject" with the government conducting a partnership relationship in order to achieve the goals and realize development programs both at the national and local scale in their respective regions. For the public or public is the opening of access for the public to obtain information relating to the public interest, open access for the public to actively participate in the process of making public policy, including access to decision making and knowing the reasons for decision making relating to the public interest. Because the real purpose of information disclosure as stated by Cain is "Citizens are unable to participate or choose properly when they are denied critical information about the government and its actions. Democratic accountability assumes that voters know what their agents are up to [and] the core obstacle to this accountability is the asymmetry of information that exists between governments and their citizens.

\section{CONCLUSION}

Setting up a local government to be able to implement the Freedom of Information Act with the aim of improving public participation in the disclosure of information is not an easy job because there are a lot of things to do. However, no matter how small the efforts and initiatives various parties have done, both of government and society to embody the visions and aims presented above can be calculated as an effort towards governance that is transparent, accountable, and participatory.

Public disclosure and bureaucratic reform are intertwined and should be mutually supportive towards each other. Disclosure of public information will not be realized if the government bureaucracy does not reform and change the paradigm of governance organization. The information which is completely closed and confined must be changed so the public can access the information they need freely. Open government as an effort of bureaucratic reform is expected to build transparency and accountability of public bodies as well as to improve the quality of public services. It is also can save the effort and budget because all the data needed is available and can be easily accessed by stakeholders of public policy and the public itself. This effort is also intended to encourage public participation directly or indirectly in any process of governance and development programs undertaken. The communities learn the importance of active participation through the media and the formation of society group. 
This study concluded that public participation has been done by Wakca Balaka forum through advocacy, monitoring, lobbying and involvement in activities that support and raise awareness about the importance of participation in the development and programs of local government in the city of Bandung. Nevertheless, it is recognized that public participation is still to be "elitist", meaning it is more accessible to NGOs or non governmental organizations. The wider community have not yet understood about public disclosure. Public participation still remains a serious problem because of the long procedure to be followed by the applicant of information and the culture of secrecy in bureaucracy as the respons to the request. In order to implement the reform of bureaucracy and public disclosure, government of Bandung has made various efforts, one of which is Bandung Open Data. Various information can be accessed by the public in web of PPID. It is also provide access for users of social media such as facebook and twitter to give feedback, criticisms, or complaints to the public bodies in Bandung. It is expected that all the efforts can lead to the better community through public participation in the context of information disclosure to create government which is transparent, accountable, and innovative.

\section{ACKNOWLEDGEMENT}

We give our gratitude to LPPM (Center of Research and Community Services) of Unisba and Ministry of Research and Higher Education of Republic of Indonesia for funding the research.

\section{BIODATA}

Dadi Ahmadi is a senior Lecturer at Faculty of Communication, Universitas Islam Bandung, Indonesia. His research interests include medium, public relation net public information disclosure, technology communication. Email: dadi@unisba.ac.id

Atie Rachmiatie is a professor at Faculty of Communication, Universitas Islam Bandung, Indonesia. Her research interests include medium, jurnalistik, radio, komunikasi publik. Email: atie@unisba.ac.id

Nursyawal is a senior Lecturer at Faculty of Communication, Universitas Islam Bandung, Indonesia. Her research interest included Public Participation, public information disclosure, Jurnalism. Email: nursyawal@gmail.com 


\section{REFERENCES}

Abdul, N., Mohd, H. \&, Ishak, S., Geynna, N., \& Awani, M. A. (2015). Empowering citizen media through investigative journalism in Malaysia (Memperkasakan media rakyat melalui kewartawanan penyiasatan di Malaysia). Jurnal Komunikasi: Malaysian Journal of Communication, 31(2), 631-647. doi: 10.17576/JKMJC-2015-3102-36

Ahmad, R. (2017). Dari parlemen ke ruang publik: Menggagas penyusunan kebijakan partisipatif. Jurnal Hukum Jentera, 2(2), 103-120. Retrieved from http://jurnal.jentera.ac.id/index.php/jentera/index

Aziz, M. (2010). Pengujian peraturan perundang-undangan dalam sistem peraturan perundang-undangan Indonesia. Jurnal Konstitusi, 7(5), 113-150.

Budi Setiyono. (2004). Birokrasi dalam perspektif politik dan administrasi (2nd ed.). Semarang: Puskodak Undip.

Creighton J. L. (2005). The public participation handbook, making better decisions through citizen involvement (1st ed.). Retrieved from https://books.google.co.id/books?hl=id\&lr=\&id=QViwxZ1vQilC\&oi=fnd\&pg=PR9\&dq $=$ THE+PUBLIC+PARTICIPATION+HANDBOOK\&ots=vnY_KZJ3JO\&sig=88xoGhQGRuJGH 3THzeK4Hju7D30\&redir_esc $=y \# v=o n e p a g e \& q=T H E$ PUBLIC PARTICIPATION HANDBOOK\& $\mathrm{f}=$ false

Fatah, R. E. S. (1994). Masalah dan prospek demokrasi di Indonesia Title (1st ed., M. Sudarsono, Juwono \& Rauf, Ed.). Retrieved from https://catalog.hathitrust.org/Record/002873486

Habermas, J. (2007). Ruang publik, sebuah kajian tentang kategori masyarakat Borjuis (2nd ed.; Y. Santoso, Ed.). Yogyakarta: Kreasi Wacana.

Hidayat, D., Kuswarno, E., Zubair, F., \& Hafiar, H. (2018). Public relations communication behavior through a local-wisdom approach: The findings of public relations components via ethnography as methodology. Jurnal Komunikasi: Malaysian Journal of Communication, 34(3), 56-72. doi: 10.17576/JKMJC-2018-3403-04

Hidayat, D. N. (2002). Metodologi penelitian dalam sebuah "multi-paradigm science." Mediator: Jurnal Komunikasi, 3(2), 197-220. doi: 10.29313/MEDIATOR.V3I2.766

Iza, R. (2011). Relevansi partisipasi masyarakat dalam perancangan pembentukan peraturan perundang-undangan yang responsif. Jurnal Simbur Cahaya, 16(2). Retrieved from http://journal.fh.unsri.ac.id/index.php/simburcahaya/issue/archive

Jacobs, L. R., Cook, F. L., \& Delli Carpini, M. X. (2009). Talking together "public deliberation and political participation in America" (1st ed.). Retrieved from https://www.amazon.com/Talking-Together-Deliberation-PoliticalParticipation/dp/0226389871

Kamaruddin, A. (2017). Analisis kualitatif terhadap faktor kegagalan komunikasi pembujukan dalam konteks pengucapan awam. Jurnal Komunikasi: Malaysian Journal of Communication, 33(3), 89-106.

Kominfo. (2008). Undang-Undang Republik Indonesia Nomor 14.

Kominfo. (2010). Pedoman pengembangan dan pemberdayaan lembaga komunikasi sosial. Retrieved from Peraturan Menteri Komunikasi dan Informatika Republik Indonesia website:

https://jdih.kominfo.go.id/produk_hukum/view/id/254/t/peraturan+menteri+komu nikasi+dan+informatika+nomor+08permkominfo062010+tanggal+01+juni+2010 
Kominfo. (2017). Pemberdayaan KIM lahirkan masyarakat cerdas informasi. Retrieved December 9, 2017, from Sorotan Media website: https://kominfo.go.id/content/detail/11882/pemberdayaan-kim-lahirkanmasyarakat-cerdas-informasi/0/sorotan_media

Komisi Informasi Daerah Jawa Barat. (2019). Hasil monitoring dan evaluasi penerapan keterbukaan informasi di Jawa Barat.

Komisi Informasi Pusat RI. (2018). Laporan implementasi keterbukaan informasi publik \& penganugerahaan keterbukaan informasi badan publik tahun 2018 (h/m. 1-10). Retrieved from https://komisiinformasi.go.id/wpcontent/uploads/2019/03/Laporan-Penganugerahan-2018.pdf

Martin, C. D. P., Salvosa, F. I. F., Exevea, C. A. G., \& Tome, P. C. (2018). Measuring the overall satisfaction of Filipino journalists on public information officers. Jurnal Komunikasi: Malaysian Journal of Communication, 34(4), 168-185. doi: 10.17576/JKMJC-20183404-10

Mas'oed, M. (2003). Politik, birokrasi dan pembangunan (1st ed.). Yogyakarta: Pustaka Pelajar.

Mulyana, D. (2001). Merancang peran baru humas dalam pengembangan otonomi daerah. MediaTor (Jurnal Komunikasi), 2(1), 1-9. doi: 10.29313/mediator.v2i1.693

Rachmiatie, A. (2001). Profil jurnalis di era Reformasi: Studi kualitatif dengan pendekatan sense making tentang profil sumber daya manusia di media cetak, radio, dan televisi. Mediator, 2(1), 101-114.

Safrudin, I. (2004). Etika emansipatoris Jurgen Habermas: Etika paradigmatik di wilayah Praksis. MediaTor (Jurnal Komunikasi), 5(1), 1-13. Retrieved from http://ejournal.unisba.ac.id/index.php/mediator/article/view/1033

Schuler, D. (2010). Online deliberation and civic intelligence. Open government: Transparency, collaboration, and participation in practice, 91-103.

Subhan, A. (2016). Mendukung transparansi pemerintah (Studi kasus keterbukaan informasi publik di provinsi Jambi). Journal Kajian, 21(3), 237-255. doi: 10.22212/kajian.v21i3.777

Tim OGI (Open Government Indonesia). (2012). Laporan pelaksanaan rencana aksi 2016 (1st ed.). $\quad$ Retrieved from https://www.opengovpartnership.org/wpcontent/uploads/2001/01/Indonesia_Mid-Term_Self-Assessment_2016-2017.pdf

Tjandra, W. R., \& Darsono, K. B. (2009). Legislative drafting: Teori dan teknik pembuatan peraturan daerah Yogyakarta (1st ed.). Yogyakarta: Universitas Atmajaya.

Wahid, U. (2013). Perempuan dan kekuasaan politik dalam pemilukada DKI Jakarta tahun 2012. Jurnal Komunikasi: Malasysian Journal of Communication, 29(1), 73-97.

Wan Norshira Wan Mohd Ghazali. (2019). Islam as the state ideology: Exploring from Gramsci's notion of power, culture and ideology. Jurnal Komunikasi: Malaysian Journal of Communication, 35(1), 338-352. doi: 10.17576/JKMJC-2019-3501-22

Widiastuti, R. N. (2019). No Title. Kompas National Newspaper, p. 8. 